\title{
FAKTOR-FAKTOR YANG MEMPENGARUHI PRODUKSI SUSU SAPI PERAH KELOMPOK TANI TERNAK SAPI PERAH (KTTSP) KANIA, KABUPATEN BOGOR
}

\author{
Adam Adinegoro, Edmon Daris* dan Zulmanery
}

\begin{abstract}
ABSTRAK
Tujuan dari penelitian ini adalah: (1) mengidentifikasi dan menganalisis faktorfaktor yang mempengaruhi produksi susu dari ternak sapi perah, dan (2) untuk menentukan elastisitas produksi susu. Penelitian ini dilakukan pada kelompok sapi perah KANIA, Bogor. Data diperoleh dari wawancara dan kuesioner dengan peternak sapi. Model regresi linear dan perhitungan elastisitas yang digunakan untuk menganalisis data dengan Excel 2007 dan perangkat lunak SPSS versi 16. Hasil analisis menunjukkan bahwa faktor-faktor yang mempengaruhi produksi susu adalah tenaga kerja, hijauan, dan konsentrat pakan . Hasil perhitungan elastisitas menunjukkan bahwa semua variabel produksi adalah variabel elastis.
\end{abstract}

Kata kunci: produksi, sapi perah, elastisitas, susu

\begin{abstract}
The purpose of this study are: (1) to identify and to analyze the factors that influence milk production of dairy cattles, and (2) to determine the elasticity of milk production. This research was conducted at the Dairy cattle group KANIA, Bogor. Data were obtained from interviews and questionnaires with cattle ranchers. Multiple linear regression models and elasticity calculations were employed to analyze the data with the Excel 2007 and software for Statistical Product and Service Solution (SPSS) version 16. Results of the analysis revealed that the factors affecting milk production is labor, forages, and feed concentrates. The result of the calculation of the elasticity indicated that all production variables are elastic variables.
\end{abstract}

Keywords: production, dairy cattle, elasticity, milk

\section{PENDAHULUAN}

Pembangunan subsektor peternakan merupakan bagian dari pembangunan sektor pertanian yang memiliki nilai strategis, antara lain dalam memenuhi kebutuhan pangan non karbohidrat yang terus meningkat akibat bertambahnya jumlah penduduk, peningkatan rata-rata pendapatan penduduk, dan penciptaan lapangan pekerjaan (Sudono, 1985:9). 
Kondisi geografis, ekologi, dan kesuburan lahan di beberapa wilayah Indonesia memiliki karakteristik yang cocok untuk pengembangan agribisnis persusuan. Selain itu, dari sisi permintaan, produksi susu dalam negeri masih belum mencukupi untuk menutupi kebutuhan konsumsi dalam negeri. Saat ini produksi dalam negeri baru bisa memasok tidak lebih dari 45 persen dari permintaan nasional.

Tabel 1. Produksi dan Konsumsi Susu Dalam Negeri Tahun 2000-2006

\begin{tabular}{|c|c|c|c|}
\hline $\begin{array}{c}\text { Wakt } \\
\text { u } \\
\text { (Tah } \\
\text { un) }\end{array}$ & $\begin{array}{c}\text { Produk } \\
\text { si Susu } \\
\text { (Ton/L } \\
\text { iter) }\end{array}$ & $\begin{array}{c}\text { Konsu } \\
\text { msi } \\
\text { Susu } \\
\text { (Ton/L } \\
\text { iter) }\end{array}$ & $\begin{array}{c}\% \\
\text { Pencap } \\
\text { aian } \\
\text { Kebutu } \\
\text { han } \\
\text { Susu }\end{array}$ \\
\hline 2000 & 495,7 & 1400 & 35,40 \\
\hline 2001 & 479,9 & 1262 & 38,02 \\
\hline 2002 & 493,4 & 1266 & 38,97 \\
\hline 2003 & 553,4 & 1517 & 36,47 \\
\hline 2004 & 549,9 & 1514 & 36,32 \\
\hline 2005 & 535,0 & 1206 & 44,36 \\
\hline 2006 & 616,5 & 1499 & 41,12 \\
\hline $\begin{array}{c}\text { TOT } \\
\text { AL }\end{array}$ & 3723,8 & 004 & 270,66 \\
\hline $\begin{array}{c}\text { Rata- } \\
\text { rata } \\
\text { total }\end{array}$ & 531,97 & $\begin{array}{c}1380,5 \\
7\end{array}$ & 38,67 \\
\hline
\end{tabular}

Sumber: Ditjen Peternakan 2007

Berdasarkan Tabel 1, total produksi susu sebesar 3723,8 ton/liter dengan rata-rata sebesar 531,97 ton/liter sedangkan total konsumsi susu sebanyak 9664 ton/liter dengan rata-rata 1380,57 ton/liter. sedangkan produksi susu dalam negeri bila dirataratakan baru mencapai 500.000 ton/liter pertahun. Adapun persentase pencapaian kebutuhan susu pada kisaran $35-45 \%$ dengan persentase tertinggi pada tahun 2005 sebesar
$44,36 \%$ dan terendah pada tahun 2000 sebesar $35,40 \%$. Fenomena tersebut menuntut suatu pembinaan dan pengembangan usaha peternakan sapi perah sehingga membuka kesempatan bagi para peternak agar lebih meningkatkan produktivitas dan kinerja manajemen usahanya untuk meningkatkan produksi susu sapi.

Kondisi geografis, ekologi, dan kesuburan lahan di beberapa wilayah Indonesia memiliki karakteristik yang cocok untuk pengembangan usaha ternak sapi perah, seperti Jawa Timur, Jawa Tengah dan Jawa Barat, hal tersebut menyebabkan pulau Jawa terus menjadi wilayah utama peternakan sapi perah di Indonesia.

Produksi susu sapi perah di Jawa Barat dari tahun 2000 sampai 2007 mengalami perkembangan rata-rata sebesar 2,87 persen, produksi susu Provinsi Jawa Barat disajikan pada Tabel 2.

Tabel 2. Produksi Susu Segar di Provinsi Jawa Barat Tahun 2000 Sampai 2007

\begin{tabular}{|c|c|c|c|}
\hline $\begin{array}{c}\text { Tahu } \\
\mathrm{n}\end{array}$ & $\begin{array}{c}\text { Produk } \\
\text { si (ton) }\end{array}$ & $\begin{array}{c}\text { Tren } \\
\mathrm{d} \\
(\%)\end{array}$ & $\begin{array}{c}\text { Kontribu } \\
\text { si } \\
\text { Terhada } \\
\mathrm{p} \\
\text { Produksi } \\
\text { Nasional } \\
(\%)\end{array}$ \\
\hline 2000 & 184,52 & & 37,23 \\
\hline 2001 & 184,83 & 0,17 & 38,51 \\
\hline 2002 & 198,51 & 7,40 & 40,23 \\
\hline 2003 & 207,86 & 4,71 & 37,56 \\
\hline 2004 & 215,33 & 3,59 & 39,16 \\
\hline 2005 & 201,86 & $-6,26$ & 37,66 \\
\hline 2006 & 211,89 & 4,97 & 34,37 \\
\hline 2007 & 233,55 & 5,50 & 35,10 \\
& $*$ & & \\
\hline
\end{tabular}

Sumber: Departemen Pertanian, 2008

* Angka Sementara 
Kemampuan produksi susu segar di Provinsi Jawa Barat tidak terlepas dari kontribusi masingmasing kabupaten dan kota yang tercakup pada wilayah Provinsi Jawa Barat. Produksi susu segar di Jawa Barat dari tahun 2000 sampai 2007 sebanyak 1.628.350 liter. Berdasarkan total produksi susu segar tersebut, sekitar 86,66 persen merupakan hasil kontribusi susu segar dari lima kabupaten yaitu Kabupaten Bandung 50,16 persen, Kabupaten Garut 18,38 persen, Kabupaten Sumedang 6,43 persen, Kabupaten Kuningan 6,32 persen dan Kabupaten Bogor 5,37 persen. Kabupaten Bogor merupakan penghasil produksi susu paling sedikit dibandingkan dengan empat kabupaten lainnya.

Perkembangan produksi susu segar kelima kabupaten tersebut memiliki trend yang berbeda-beda. Kabupaten Bandung memiliki perkembangan produksi susu dari tahun 2003 sampai tahun 2007 ratarata 5,57 persen, Kabupaten Sumedang rata-rata 15,71 persen, Kabupaten Bogor rata-rata 0,64 persen, Kabupaten Garut rata-rata 5,23 persen dan Kabupaten Kuningan rata-rata $-7,54$ persen.

Tabel 3. Persentase Perubahan Produksi Susu Sapi Perah Kabupaten Bandung, Sumedang, Bogor, Garut dan Kuningan.

\begin{tabular}{|l|l|l|l|l|l|}
\hline Tahun & \multicolumn{5}{|c|}{ Kabupaten } \\
\cline { 2 - 6 } & $\begin{array}{l}\text { Bandung } \\
(\%)\end{array}$ & $\begin{array}{l}\text { Sumedang } \\
(\%)\end{array}$ & Bogor $(\%)$ & Garut $(\%)$ & $\begin{array}{l}\text { Kuningan } \\
(\%)\end{array}$ \\
\hline 2003 & - & - & - & - & - \\
\hline 2004 & 2,50 & 10,01 & 4,00 & 2,00 & $-3,55$ \\
\hline 2005 & 12,70 & 7,66 & 1,47 & $-46,22$ & $-9,33$ \\
\hline 2006 & 5,66 & 12,44 & $-5,74$ & 10,58 & $-5,24$ \\
\hline 2007 & 1,43 & 32,71 & 2,83 & 12,73 & $-12,04$ \\
\hline $\begin{array}{l}\text { Rata- } \\
\text { rata }\end{array}$ & 5,57 & 15,71 & 0,64 & $-5,23$ & $-7,54$ \\
\hline
\end{tabular}

Sumber: Dinas Peternakan Provinsi Jawa Barat, 2008 (diolah)

Sumbangan produksi susu di Kabupaten Bogor berasal dari kelompok ternak, salah satu kelompok ternak sapi perah yang ada di Kabupaten Bogor adalah Kelompok Tani Ternak Sapi Perah (KTTSP) KANIA. Kelompok Tani Ternak Sapi Perah (KTTSP) KANIA dibentuk berdasarkan hasil musyawarah antar peternak sapi perah di desa Tajurhalang kecamatan Cijeruk Kabupaten Bogor untuk menyatukan peternak yang ada di desa Tajur Halang dan menyatukan tujuan bersama dalam usaha peternakan sapi perah. Skala usaha dalam KTTSP Kania merupakan skala usaha rakyat dengan kepemilikan ternak satu sampai tiga ekor per peternak.

Penelitian faktor-faktor yang berpengaruh terhadap produktivitas sapi perah yang dipelihara peternak akan mengungkapkan faktor-faktor teknis penentu besarnya kemampuan produksi ternak menghasilkan susu. Berdasarkan uraian permasalahan yang ada, maka perlu dilakukan penelitian dengan judul "Analisis Faktor-Faktor yang Mempengaruhi Produksi Susu Sapi Perah (Studi Kasus Kelompok Tani Ternak Sapi Perah KANIA, Kabupaten Bogor)". 


\section{METODE PENELITIAN}

\section{Lokasi dan Waktu Penelitian}

Penelitian ini dilaksanakan di Kelompok Tani Ternak Sapi Perah (KTTSP) Kania, desa Tajur Halang, kecamatan Cijeruk, kabupaten Bogor, Jawa Barat. Lokasi penelitian dipilih secara purposive (sengaja), berdasarkan pertimbangan Kania merupakan kelompok ternak yang mewadahi para anggota peternak yang ada di desa tajur halang, Kabupaten Bogor serta memiliki banyak prestasi, diantaranya sebagai kelompok ternak yang memiliki tingkat produktivitas terbaik dalam KPS Bogor. Penelitian ini dilakukan pada bulan Januari 2012. Periode tersebut digunakan untuk memperoleh data dan keterangan dari pihak-pihak berkepentingan dengan penelitian, sebanyak dan selengkap mungkin.

\section{Jenis dan Sumber Data}

Data yang dikumpulkan dalam penelitian ini adalah data primer dan data sekunder.

a. Data Primer

Dikumpulkan dengan cara observasi langsung di lapangan dan wawancara responden dengan menggunakan pertanyaan yang telah dipersiapkan sebelumnya.

\section{b. Data Sekunder}

Data sekunder diambil dari instansi yang terkait dengan topik penelitian antara lain berasal dari Kantor Kecamatan, Dinas Pertanian, Dinas Peternakan, Teks Book, laporan yang semua dikumpulkan guna menunjang tercapainya tujuan penelitian. Data yang diambil antara lain jumlah penduduk, jumlah sapi perah dan jumlah peternak sapi perah.

\section{Metode Penentuan Jumlah Sampel Populasi}

Populasi penelitian adalah peternak sapi perah yang menjadi anggota Kelompok Tani Ternak Sapi Perah (KTTSP) KANIA kabupaten Bogor. Jumlah populasi peternak yang menjadi anggota berjumlah 48 peternak sapi perah. Populasi responden penelitian memiliki karakteristik yang beragam dan memiliki jumlah populasi ternak sapi perah yang dipeliharanya.

\section{Sampel}

Metode pengambilan sampel dilakukan secara purposive (sengaja), dengan jumlah populasi peternak sapi perah berjumlah 48 orang. Berdasarkan jumlah populasi tersebut peneliti mengambil sampel 32 responden, pengambilan sampel berdasarkan bahwa sampel yang diambil sudah homogen sehingga 32 sampel sebagai responden sudah dapat mewakili dari keseluruhan populasi.

\section{Metode Pengumpulan Data}

1. Observasi, yaitu dengan melakukan pengamatan langsung terhadap objek yang akan diteliti. Dalam hal ini pengamatan langsung ke kelompok ternak sapi perah Kania dengan melihat faktor faktor yang mempengaruhi produksi peternak sapi perah.

2. Wawancara, yaitu salah satu tekhnik pengumpulan data dan informasi dengan mewawancarai anggota peternak sapi perah Koperasi Kania.

3. kuesioner (daftar pertanyaan), yaitu salah satu tekhnik pengumpulan data dan informasi dengan cara menyebarkan angket (daftar pertanyaan) kepada responden anggota peternak sapi 
perah Koperasi Kania yang dijadikan sampel penelitian.

4. Studi kepustakaan, yaitu mengumpulkan data dan informasi melalui telaah berbagai literatur yang relevan yang berhubungan dengan permasalahan yang ada didalam penulisan skripsi ini, dapat diperoleh dari buku buku, Departemen Pertanian, Dinas peternakan dan departemen terkait, internet dan lain lain.

\section{Metode Pengolahan Data}

Metode yang digunakan dalam mengolah dan menganalisis data produksi pakan ternak yaitu analisis kuantitatif melalui model persamaan regresi linear berganda. Metode ini digunakan karena diharapkan dapat menjelaskan faktor-faktor yang berhubungan nyata dan tidak berhubungan nyata terhadap produksi susu sapi di kelompok tani ternak sapi perah (KTTSP) Kania, kabupaten Bogor. Alat atau instrumen perhitungan yang digunakan dalam penelitian ini yaitu cara komputerisasi dengan menggunakan software Excell 2007 dan Statistical Product for Service Solution (SPSS) versi 16.

Menurut Suyanto (2004:195), analisis regresi linear berganda digunakan untuk menganalisis pengaruh lebih dari satu variabel independen terhadap variabel dependen. Persamaan umum regresi linear berganda adalah sebagai berikut:

$$
\begin{gathered}
\mathrm{Y}=\mathrm{b}_{0}+\mathrm{b}_{1} \mathrm{X}_{1}+\mathrm{b}_{2} \mathrm{X}_{2}+\mathrm{b}_{3} \mathrm{X}_{3} \\
+\ldots \ldots . .+\mathrm{e}
\end{gathered}
$$

Tabel 3. Definisi Operasional

\begin{tabular}{|l|l|l|l|}
\hline Variabel & Kode & Variabel & Skala Pengukuran \\
\hline Dependen & $\mathrm{Y}$ & Output & Liter \\
\hline Independen & $\mathrm{X}_{1}$ & Tenaga Kerja & HOK \\
& $\mathrm{X}_{2}$ & Pakan Hijauan & Kilogram \\
& $\mathrm{X}_{3}$ & Pakan Konsentrat & Kilogram \\
& & & \\
& & & \\
& $\mathrm{b} 0$ & intersep & \\
& $\mathrm{b}_{1-3}$ & koefisien regresi & \\
& $\mathrm{e}$ & eror & \\
\hline
\end{tabular}

\section{Uji Kelayakan Model}

Adapun pengujian dalam uji kelayakan model antara lain yaitu:

a. Uji Multikolinearitas

Multikolinearitas adalah ada tidaknya suatu hubungan liniear yang sempurna atau yang mendekati sempurna antara beberapa atau semua variabel bebas dalam persamaan. Cara untuk mendeteksi ada tidaknya multikolinearitas dalam model adalah sebagai berikut:
1. Nilai R2, nilai Fhitung yang dihasilkan sangat tinggi, namun secara individual variabelvariabel independen banyak yang tidak signifikan mempengaruhi variabel dependen.

2. Melakukan regresi parsial dengan cara:

a) Mengestimasi model awal dalam persamaan sehingga mendapat nilai $\mathrm{R} 2$ 
b) Menggunakan auxilary regression pada masingmasing variabel independen

c) Membandingkan nilai R2 dalam model persamaan awal dengan R2 pada model regresi parsial. Jika nilai $\mathrm{R} 2$ dalam regresi parsial lebih tinggi maka terdapat multikolinearitas.

\section{b. Uji Heteroskedastisitas}

Heteroskedastisitas merupakan gangguan atau hambatan yang tidak menyebar secara normal pada sebaran sampel, berarti bahwa variasi residual tidak sama untuk semua pengamatan. Heteroskedasitas juga bertentangan dengan salah satu asumsi dasar regresi homoskedasitas yaitu variasi residual sama untuk semua pengamatan.

\section{c. Uji Autokorelasi}

Autokorelasi adalah korelasi antara anggota serangkaian observasi yang diurut menurut waktu dan ruang. Autokorelasi muncul karena observasi yang beruntun sepanjang waktu berkaitan satu sama lain. Masalah ini timbul karena residu (kesalahan pengganggu) tidak bebas dari satu observasi lainnya. Hal ini sering ditemukan pada jenis data time series.

\section{Uji Analisis Regresi Berganda}

Analisis regresi berganda dilakukan untuk menguji signifikansi dari variabel dalam penelitian yang dilakukan, yaitu dengan cara:

1. Uji Serentak Seluruh Parameter Dugaan (Uji F)

Uji $F$ merupakan pengujian untuk mengetahui angka pengaruh variabel independen terhadap variabel dependen secara bersama-sama.

\section{Uji Parameter Regresi Secara Tunggal (Uji t)}

Uji $\mathrm{t}$ merupakan angka yang menunjukan signifikansi dari pengaruh variabel independen secara individu terhadap variabel dependen dengan manganggap variabel lainnya bersifat konstan.

\section{Uji Koefisien Determinasi (R2)} Koefisien determinasi (R2) merupakan angka yang menunjukkan besarnya variabel terikat dapat dijelaskan oleh variabel bebas secara bersama-sama. Rumus dari uji R2 adalah sebagai berikut :

$$
\mathrm{R}^{2}=\frac{\overline{\mathrm{\Sigma}(\hat{\mathrm{Y}}-\overline{\mathrm{Y}}) 2}}{\mathrm{\Sigma}(\mathrm{Yi}-\overline{\mathrm{Y}})^{2}}
$$

\section{Definisi Operasional}

Definisi operasional yang digunakan dalam penelitian ini adalah:

1. Susu adalah cairan berwarna putih yang dihasilkan dari hewan atau ternak setelah melalui proses pemerahan.

2. Sapi laktasi adalah sapi yang dapat menghasilkan air susu (telah beranak), sapi laktasi ini terdiri dari sapi laktasi yang berproduksi (laktasi kosong, laktasi bunting), dan sapi laktasi tidak berproduksi (sapi laktasi kering kandang).

3. Produksi susu adalah jumlah hasil yang diperoleh dari kegiatan peternak, diukur dalam literan susu yang dihasilkan per liter per hari.

4. Tenaga Kerja adalah banyaknya tenaga kerja yang dicurahkan dalam proses produksi pakan ternak yang dihitung berdasarkan jumlah tenaga kerja yang digunakan yang dikonversi dalam HOK.

5. Pakan Hijauan adalah makanan ternak berserat kasar tinggi yang dikonsumsi oleh ternak. 
6. Pakan konsentrat adalah bahan makanan tambahan berupa serat kasar rendah dan bersifat mudah dicerna oleh ternak.

\section{HASIL DAN PEMBAHASAN}

\section{Analisis Faktor-Faktor yang Mempengaruhi Produksi Susu Sapi di KTTSP Kania}

Data yang diperoleh berdasarkan hasil kuisioner dengan jumlah sampel sebanyak 32 responden, didapatkan data bahwa jumlah produksi total yang dihasilkan oleh peternak sapi perah di KTTSP
Kania selama satu masa laktasi atau Sembilan bulan yaitu sebesar 307.450 liter, dengan jumlah rata-rata produksi sebanyak 12.298 liter.

Pengambilan data untuk variabel penelitian dilakukan dengan mengambil jumlah sampel sebanyak 32 responden dari populasi sebanyak 48 peternak, didapatkan bahwa Penggunaan tenaga kerja pada produksi susu sapi di KTTSP Kania menggunakan satuan hari orang kerja (HOK) dengan total $16.115 \mathrm{HOK}$, rata-rata $\mathrm{HOK}$ berjumlah $644,6 \mathrm{HOK}$.

Tabel 6. Data Faktor-faktor yang Mempengaruhi Produksi Susu per Masa Laktasi (9 bulan).

\begin{tabular}{|c|c|c|c|c|}
\hline Responden & Produksi (Y) & $\mathrm{TK}\left(\mathrm{X}_{1}\right)$ & $\begin{array}{c}\text { Pakan hijauan } \\
\left(\mathrm{X}_{2}\right)\end{array}$ & $\begin{array}{c}\text { Pakan konsentrat } \\
\left(\mathrm{X}_{3}\right)\end{array}$ \\
\hline 1 & 38500 & 1320 & 134750 & 38500 \\
\hline 2 & 26400 & 1045 & 132000 & 16500 \\
\hline 3 & 1925 & 275 & 8250 & 1375 \\
\hline 4 & 3850 & 275 & 33000 & 6600 \\
\hline 5 & 23375 & 1320 & 88000 & 15400 \\
\hline 6 & 38500 & 1320 & 275000 & 22000 \\
\hline 7 & 12375 & 275 & 33000 & 4950 \\
\hline 8 & 4125 & 275 & 11000 & 2750 \\
\hline 9 & 2750 & 275 & 13750 & 2750 \\
\hline 10 & 4675 & 550 & 44000 & 2200 \\
\hline 11 & 12375 & 275 & 41250 & 5500 \\
\hline 12 & 5500 & 550 & 11000 & 5500 \\
\hline 13 & 41250 & 1320 & 247500 & 1237.5 \\
\hline 14 & 8250 & 275 & 11000 & 1650 \\
\hline 15 & 41250 & 1540 & 144375 & 2200 \\
\hline 16 & 2750 & 495 & 11000 & 1100 \\
\hline 17 & 2200 & 495 & 9625 & 2750 \\
\hline 18 & 2200 & 495 & 19250 & 2200 \\
\hline 19 & 2475 & 495 & 12375 & 2200 \\
\hline 20 & 1375 & 495 & 9625 & 2200 \\
\hline 21 & 5500 & 495 & 22000 & 2750 \\
\hline 22 & 6600 & 495 & 24750 & 4400 \\
\hline 23 & 6875 & 495 & 22000 & 5500 \\
\hline 24 & 5500 & 770 & 16500 & 2750 \\
\hline
\end{tabular}




\begin{tabular}{|c|c|c|c|c|}
\hline 25 & 6875 & 495 & 24750 & 3850 \\
\hline 26 & 8250 & 495 & 24750 & 3300 \\
\hline 27 & 17875 & 495 & 37125 & 11000 \\
\hline 28 & 4400 & 275 & 8250 & 1650 \\
\hline 29 & 2750 & 275 & 11000 & 1100 \\
\hline 30 & 2200 & 275 & 9625 & 2200 \\
\hline 31 & 2750 & 275 & 8250 & 1650 \\
\hline 32 & 4400 & 495 & 22000 & 2200 \\
\hline
\end{tabular}


Faktor Kedua dalam penelitian ini yaitu faktor pakan hijauan, penggunaan pakan hijauan pada produksi susu sapi pada KTTSP Kania menggunakan satuan kilogram $(\mathrm{Kg})$. penggunaan pakan hijauan untuk pakan ternak sapi dengan jumlah total pakan hijauan 1.399.750 Kg, rata-rata penggunaan pakan hijauan $55.950 \mathrm{~kg}$. Penggunaan pakan hijauan terbanyak dengan jumlah 275.000 $\mathrm{Kg}$, sedangkan penggunaan pakan hijauan paling sedikit dengan jumlah $8.250 \mathrm{Kg}$. Faktor ketiga yaitu pakan konsentrat, penggunaan pakan konsentrat pada produksi susu sapi pada KTTSP Kania menggunakan satuan (Kg). Penggunaan pakan konsentrat untuk pakan ternak sapi dengan jumlah total pakan konsentrat $158.813 \mathrm{Kg}$, rata-rata penggunaan pakan konsentrat $6352,5 \mathrm{Kg}$. Penggunaan pakan konsentrat terbanyak dengan jumlah $15400 \mathrm{Kg}$, sedangkan penggunaan pakan konsentrat paling sedikit dengan jumlah $1100 \mathrm{Kg}$.

\section{Uji Statistik Faktor-faktor yang Mempengaruhi Produksi Susu}

Penelitian ini terdiri dari dua variabel, yaitu variabel $\mathrm{Y}$ dan variabel $\mathrm{X}$. Variabel $\mathrm{Y}$ adalah produksi susu sapi, yaitu jumlah produksi susu sapi selama satu masa laktasi dalam satuan liter. Untuk faktor-faktor yang mempengaruhinya merupakan variabel $\mathrm{X}$. Terdapat tiga variabel dalam penelitian ini yaitu: tenaga kerja, pakan hijauan dan pakan konsentrat. Variabel X1 adalah faktor tenaga kerja (dalam satuan $\mathrm{HOK}$ ), variabel X2 adalah faktor pakan hijauan (dalam satuan $\mathrm{kg}$ ), dan variabel X3 adalah faktor pakan konsentrat (dalam satuan kg). Berdasarkan hasil perhitungan menggunakan alat bantu SPSS 16, hasil yang diperoleh untuk perhitungan regresi berganda faktor-faktor yang mempengaruhi produksi pakan ternak disajikan pada Tabel 7.

\begin{tabular}{|c|c|c|c|c|c|}
\hline $\begin{array}{l}\text { No } \\
\text {. }\end{array}$ & $\begin{array}{l}\text { Ura } \\
\text { ian }\end{array}$ & $\begin{array}{l}\text { Kons } \\
\text { tanta }\end{array}$ & $\begin{array}{l}\text { Ten } \\
\text { aga } \\
\text { Ker } \\
\text { ja }\end{array}$ & $\begin{array}{l}\text { Pak } \\
\text { an } \\
\text { Hija } \\
\text { uan }\end{array}$ & $\begin{array}{l}\text { Pakan } \\
\text { Kons } \\
\text { entrat }\end{array}$ \\
\hline 1 & $\begin{array}{l}\text { Koe } \\
\text { fisie } \\
\mathrm{n} \\
\text { Reg } \\
\text { resi }\end{array}$ & $\begin{array}{l}- \\
2016 . \\
891\end{array}$ & $\begin{array}{l}11 . \\
800\end{array}$ & $\begin{array}{l}0.10 \\
3\end{array}$ & 0.204 \\
\hline 2 & $\begin{array}{l}\text { T } \\
\text { hitu } \\
\text { ng }\end{array}$ & $\begin{array}{l}- \\
1.295\end{array}$ & $\begin{array}{l}3.1 \\
88\end{array}$ & $\begin{array}{l}5.11 \\
1\end{array}$ & 1.737 \\
\hline 3 & $\begin{array}{l}\text { F } \\
\text { hitu } \\
\text { ng }\end{array}$ & \multicolumn{4}{|c|}{$\begin{array}{c}89.2 \\
09\end{array}$} \\
\hline 4 & $R^{2}$ & \multicolumn{4}{|c|}{$\begin{array}{c}0.89 \\
5\end{array}$} \\
\hline 5 & $\begin{array}{l}\text { Kor } \\
\text { elas } \\
\mathrm{i} \\
\text { Pea } \\
\text { rson }\end{array}$ & & $\begin{array}{l}0.8 \\
93\end{array}$ & $\begin{array}{l}0.92 \\
0\end{array}$ & 0.631 \\
\hline 6 & $\begin{array}{l}\text { Dur } \\
\text { bin } \\
\text { Wat } \\
\text { son }\end{array}$ & \multicolumn{4}{|c|}{$\begin{array}{c}1.70 \\
9\end{array}$} \\
\hline
\end{tabular}

Berdasarkan hasil regresi pada Tabel 7, dapat dibentuk persamaan regresi berganda untuk faktor-faktor yang mempengaruhi produksi susu sapi perah. Sesuai dengan model persamaan regresi yang telah dijabarkan pada metodologi penelitian, maka persamaan regresi untuk faktor-faktor yang mempengaruhi produksi susu sapi perah: $\mathrm{Y}=-2016,891+11,800 \mathrm{X} 1+0,103 \mathrm{X} 2$ $+0,204 X 3$

Berdasarkan persamaan tersebut diperoleh nilai konstanta -2016,891, angka tersebut berarti bahwa produksi susu sapi akan bernilai -2016,891 bila variabel X1, X2, dan X3 bernilai sama dengan nol.

Koefisien variabel tenaga kerja (X1) dihasilkan nilai sebesar 11,800, Tanda positif ini menunjukkan hubungan yang searah atau berbanding lurus antara tenaga kerja dengan 
produksi susu sapi, dengan kata lain apabila ada penambahan tenaga kerja sebanyak satu HOK maka terjadi penambahan jumlah produksi susu sapi sebesar 11,800 liter.

Koefisien regresi untuk pakan hijauan (X2) bernilai positif sebesar 0.103. Tanda positif ini menunjukkan pengaruh yang searah antara paka hijauan dengan jumlah produksi susu sapi. Perhitungan regresi berganda untuk koefisien regresi pakan konsentrat (X3) bernilai positif sebesar 0.204. Tanda positif ini menunjukan pengaruh yang searah antara pakan konsentrat dengan produksi susu sapi.

Hasil perhitungan uji regresi berganda faktor-faktor yang mempengaruhi produksi pakan ternak adalah sebagai berikut:

a. Pengujian Koefisien Determinasi (R2)

Berdasarkan Tabel 7 didapatkan nilai koefisien determinasi dari persamaan regresi adalah sebesar 0,905 dengan nilai koefisien determinasi yang disesuaikan sebesar 0,895. karena persamaan regresi menggunakan lebih dari satu variabel, maka koefisien determinasi yang baik untuk digunakan dalam menjelaskan persaman ini adalah koefisien determinasi yang disesuaikan.

\section{b. Pengujian Serentak Seluruh Parameter Dugaan (Uji F) \\ Hasil perhitungan uji $\mathrm{F}$ dapat dilihat} pada Tabel 7, diperoleh nilai $F$ hitung sebesar 89,209 lebih besar dari F tabel $(1,96)$ dengan tingkat kepercayaan sebesar 95\% dan memiliki nilai signifikansi 0,000 lebih kecil dari $\alpha(0,05)$. Berdasarkan hasil perhitungan tersebut maka dapat disimpulkan bahwa $\mathrm{H} 0$ ditolak dan koefisien regresi signifikan secara statistik.

\section{c. Pengujian Parameter Regresi Secara Tunggal (Uji T)}

Berdasarkan Tabel 7 dapat dilihat bahwa semua variabel bebas dapat mempengaruhi produksi pakan ternak. Hasil perhitungan membuktikan bahwa terdapat dua variabel yang berpengaruh nyata pada tingkat kepercayaan 95\%. Variabel tersebut yaitu tenaga kerja, pakan hijauan. Variabel pakan konsentrat berpengaruh nyata pada tingkat kepercayaan $90 \%$.

Pada tingkat kepercayaan $95 \%$ didapat t tabel sebesar 2,064. Faktor pertama yaitu tenaga kerja (X1) t hitung bernilai 3,188 dan lebih besar dari t tabel serta memiliki nilai signifikansi lebih kecil dari nilai $\alpha(0,004<$ 0,05). Faktor kedua yaitu pakan hijauan (X2), nilai t hitung bernilai 5,111 berarti lebih besar dari nilai $t$ tabel $(2,064)$ pada tingkat kepercayaan $95 \%$ serta memiliki nilai signifikansi lebih kecil dari nilai $\alpha(0,00<$ 0,05). Faktor ketiga adalah pakan konsentrat (X3), nilai t hitung bernilai 1,737 berarti lebih kecil dari $t$ tabel (2,064) pada tingkat kepercayaan $95 \%$ serta memiliki nilai signifikansi lebih besar dari nilai $\alpha(0.204>$ $0,05)$.

\section{Interpretasi Faktor-Faktor yang Mempengaruhi Produksi Susu Sapi di KTTSP Kania}

Berdasarkan penjelasan pengujian statistik, maka didapatkan hasil bahwa uji koefisien determinasi (R2) yaitu bernilai 0,895 atau dengn kata lain $89,5 \%$ produksi susu sapi dapat dijelaskan oleh seluruh faktor dalam penelitian ini.

Faktor yang berpengaruh terhadap produksi susu sapi adalah tenaga kerja. Faktor tenaga kerja yang dihitung dalam penelitian ini adalah jumlah tenaga kerja yang digunakan dalam satu hari kerja dalam HOK, dalam proses produksi susu sapi dibutuhkan jumlah tenaga kerja dan jumlah jam kerja yang menuntut untuk selalu bekerja siang dan malam setiap hari. Sapi yang dalam masa laktasi dibutuhkan penanganan yang lebih intensif untuk dapat berproduksi secara optimal.

Hubungan korelasi antara tenaga kerja dengan produksi susu sapi yaitu 0,893. Angka ini menunjukkan bahwa memiliki 
hubungan atau korelasi sangat kuat, searah dan signifikan. Hasil perhitungan regresi berganda menyatakan bahwa faktor tenaga kerja dapat mempengaruhi produksi susu sapi pada tingkat kepercayaan 95\%, dan koefisien regresi bernilai positif 11,800

Faktor kedua adalah variabel pakan hijauan yang diduga juga berpengaruh terhadap produksi susu sapi. Pada penelitian ini variabel pakan hijauan dihitung berdasarkan jumlah pakan hjauan dalam $\mathrm{kg} / \mathrm{hari}$.

Hubungan korelasi antara pakan hijauan dengan produksi susu sapi dapat dilihat dari nilai korelasi yaitu 0,920. Angka ini berarti bahwa antara pakan hijauan dengan produksi susu sapi memiliki hubungan atau korelasi sangat kuat, searah dan signifikan.

Faktor ketiga adalah variabel terakhir pada perhitungan regresi berganda yaitu variabel pakan konsentrat yang diduga juga mempengaruhi produksi susu sapi. Variabel pakan konsentrat yang dihitung dalam penelitian ini berdasarkan jumlah $\mathrm{kg} / \mathrm{hari}$.

Hubungan korelasi antara pakan konsentrat dengan produksi susu sapi dapat dilihat dengan nilai korelasi variabel yaitu 0,631, angka ini menunjukkan bahwa hubungan atau korelasi antara pakan konsentrat dengan produksi susu sapi cukup kuat, searah dan signifikan.

\section{Elastisitas Produksi}

Secara ringkas hasil perhitungan elastisitas produksi susu sapi pada kelompok tani ternak sapi perah (KTTSP) Kania, kabupaten Bogor disajikan pada Tabel 8.

Tabel 8. Hasil Analisis Elastisitas Produksi Susu Sapi pada KTTSP Kania.

\begin{tabular}{|l|l|l|l|l|}
\hline No. & $\begin{array}{l}\text { Varia } \\
\text { bel }\end{array}$ & $\begin{array}{l}\text { Koefis } \\
\text { ien } \\
\text { regresi }\end{array}$ & $\begin{array}{l}\text { Elasti } \\
\text { sitas }\end{array}$ & $\begin{array}{l}\text { Interpr } \\
\text { etasi }\end{array}$ \\
\hline 1 & $\begin{array}{l}\text { Tena } \\
\text { ga }\end{array}$ & 11,800 & 0.630 & $\begin{array}{l}\text { In } \\
\text { elastic }\end{array}$ \\
\hline
\end{tabular}

\begin{tabular}{|c|c|c|c|c|}
\hline & $\begin{array}{l}\text { Kerja } \\
\text { (X1) }\end{array}$ & & & \\
\hline 2 & $\begin{array}{l}\text { Pakan } \\
\text { Hijau } \\
\text { an } \\
\text { (X2) }\end{array}$ & 0,103 & 0.447 & $\begin{array}{l}\text { In } \\
\text { elastic }\end{array}$ \\
\hline 3 & $\begin{array}{l}\text { Pakan } \\
\text { Kons } \\
\text { entrat } \\
\text { (X3) }\end{array}$ & 0,204 & 0.106 & $\begin{array}{l}\text { In } \\
\text { elastic }\end{array}$ \\
\hline
\end{tabular}

Berdasarkan Tabel 8 dapat didapatkan hasil bahwa dalam penelitian ini semua variabel didalam penelitian ini memiliki nilai yang in elastis yaitu kurang dari 1. Faktor tenaga kerja dalam penelitian ini bersifat in elastis dengan nilai 0,630 , hal ini dikarenakan penggunaan tenaga kerja pada kelompok ternak Kania tidak efisien dan kurang terampil.

Faktor produksi pakan hijauan dalam penelitian ini bersifat in elastis dengan nilai 0,469 hal ini sudah sesuai dengan teori bahwa dalam memproduksi susu sapi pemberian pakan hijauan yang mangandung kadar serat tinggi tidak langsung mempengaruhi produksi susu.

Faktor produksi pakan konsentrat dalam penelitian ini bersifat in elastis dengan nilai 0,106 . Hal ini sudah sesuai teori bahwa pakan konsentrat tidak langsung mempengaruhi produksi susu karena membutuhkan waktu untuk proses pencernaan pada tubuh sapi.

\section{KESIMPULAN}

Berdasarkan hasil analisis terhadap faktor-faktor produksi yang mempengaruhi produksi susu pada kelompok tani ternak sapi perah (KTTSP) Kania kabupaten Bogor, maka dapat disimpulkan sebagai berikut:

1. Faktor-faktor yang mempengaruhi produksi susu sapi pada kelompok tani sapi perah (KTTSP) Kania yang dianalisis dalam penelitian ini adalah 
tenaga kerja, pakan hijauan dan pakan konsentrat. Faktor yang paling berpengaruh terhadap tingkat produksi susu yaitu curahan tenaga kerja dengan nilai koefisien 11,800 dan faktor tenaga kerja dengan nilai koefisien 0,103 pada taraf kepercayaan 95\%. Variabel pakan konsentrat berpengaruh nyata pada taraf kepercayaan $90 \%$ dengan nilai koefisien regresi 0,204.

2. Respon produksi terhadap perubahan faktor-faktor yang mempengaruhi produksi pada penelitian ini diketahui bahwa semua variabel bebas dalam penelitian bersifat in elastis atau tidak respon terhadap variabel dependen, dengan kata lain variabel tenaga kerja, pakan hijauan dan pakan konsetrat tidak respon terhadap produksi susu sapi.

\section{DAFTAR PUSTAKA}

Akoso, Budi Tri. Kesehatan Sapi. (Yogyakarta: Kanisius, 1996).

Anggorodi, R. Ilmu Makanan Ternak Umum. (Jakarta: Gramedia, 1979).

Bamualim, Abdullah M, Kusmartono, dan Kuswandi. Aspek Nutrisi Sapi Perah. Badan Penelitian dan Pengembangan Pertanian, Departemen Pertanian. Bogor, 2009.

Daniel, Moechtar. Metode Penelitian Sosial Ekonomi. (Jakarta: Bumi Aksara, 2002).

Daniel, Moechtar. Pengantar Ekonomi Pertanian. (Jakarta: Bumi Aksara, 2004).

Debertin, David L. Agricultural Production Economics. (Amerika: Macmillan Publishing Company, 1986) (T ransliterasi, Interpretasi, dan Penulisan
Kembali oleh Tatiek Koerniawati, SP.MP).

Firman, Achmad. Agribisnis Sapi Perah. Bandung: widya padjajaran, 2010.

Irianto, Agus. Statistik Konsep Dasar \& Aplikasinya. (Jakarta: Kencana, 2004).

Koutsoyiannis. Theory of Econometrics Method. (USA: Macmillan, 1997).

Nachrowi, Djalal Nachrowi, dan Hardius Usman. Penggunaan Teknik Ekonometri. (Jakarta: PT. Raja Grafindo Persada, 2002).

Nazir, Moh. Metode Penelitian. (Bogor: Ghalia Indonesia, 2005).

Nur, K.S. Mengupayakan Usaha Sapi Perah Tetap Bertahan. Poultry Indonesia. Gappi. No 291. Pp 64-65, 2004

Rasyaf, Muhammad. Memasarkan Hasil Peternakan. (Jakarta: Swadaya, 1996)

Ritonga, dkk. Pelajaran Ekonomi Jilid 1. (Jakarta: Erlangga, 2003).

Sasongko, Ribut. Sanitasi dan Kesehatan Sapi Perah. Poultry Indonesia. PT Surya Prabha. No 75. Pp 58, 1986.

Soekartawi. Teori Ekonomi Produksi dengan Pokok Bahasan Analisis Fungsi CobDouglas. (Jakarta: PT. Raja Grafindo Persada, 2003).

Sudono. Beternak Sapi Perah Secara Intensif. (Jakarta: Agromedia Pustaka, 1985)

Sulaiman, Wahid. Analisis Regresi Menggunakan SPSS. (Yogyakarta: Andi, 2004) 
Suyanto, Bagong. Metode Penelitian Sosial. (Jakarta: Kencana Prenada Media Group, 2008).

Walpole, Ronald E. Pengantar Statistika Edisi 3. (Jakarta: PT. Gramedia Pustaka Utama, 1995)

Williamson. G dan W.J.A Payne. 1993. Pengantar Peternakan di Daerah Tropis. (Yogyakarta: UGM Press, 1993)

Heriyatno. "Analisis Pendapatan dan Faktor yang Mempengaruhi Produksi Susu Sapi Perah di Tingkat Peternak (Kasus Anggota Koperasi Serba Usaha Karya Nugraha Kecamatan Cigugur Kabupaten Kuningan Provinsi Jawa Barat)”. 2009

Sihite. "Keberhasilan Usaha Peternakan Sapi Perah dalam Kaitannya dengan Faktorfaktor Produksi yang Mempengaruhinya di Kecamatan Sukabumi, Kabupaten Sukabumi”. 1998

www.ditjennak.go.id/t-petasitus.asp. Diakses pada tanggal 15 januari 2012.

http://pse.litbang.deptan.go.id. Diakses pada tanggal 15 Januari 2011

* Alamat Korespondensi:

edmon.daris@uinjkt.ac.id 